\title{
Infografis Dinamis Sebagai Pengganti Peta Konvensional pada Kawasan Bermain (Studi Kasus : Dunia Fantasi)
}

\author{
Anny Valentina, Richard Andrew \\ Fakultas Seni Rupa dan Desain, Fakultas Ekonomi, Universitas Tarumanagara \\ Jl. Letjen S Parman No 1, Jakarta Barat 11440 \\ annyv@fsrd.untar.ac.id, richarda@fe.untar.ac.id
}

\begin{abstract}
A map that was originally used as a hint tool to visit a new area. Start from visiting the new city to the play area. Dunia Fantasi (Dufan) is a large playing area. Until now Dufan provides a map of the area in the form of brochures and standing maps in the play area. With the advancement of technology today is very possible if Dufan can make the navigation system map of its region in digital form. As is known today human habits have changed a lot, because it is very likely to move the map from manual to digital system will be preferred by consumers. Digital map is considered to be more practical and easy, especially if the form of dynamic infographic. Infographics itself is a collection of information with the help of images, dynamic use can be interpreted with the addition of motion elements in the map. Using data collection techniques in the form of direct observation and interview. The target of the research is for Dufan visitors covering all ages, ranging from students, students and families and through this research is expected to know what information needed by visitors and media and design that is considered efficient and easy to understand, so through the media map can increase consumer satisfaction.
\end{abstract}

Keywords: navigation system, media, dynamics info graphic, consumer satisfaction

\begin{abstract}
Abstrak
Peta yang pada awalnya digunakan sebagai alat bantu petunjuk untuk mengunjungi sebuah area bar. Mulai dari mengunjungi kota baru hingga area bermain. Dunia Fantasi (Dufan) merupakan kawasan bermain yang cukup luas. Hingga saat ini Dufan menyediakan peta area dalam bentuk brosur dan standing map yang ada di kawasan bermain. Kemajuan teknologi saat ini memungkinkan Dufan bisa membuat sistem navigasi peta kawasannya dalam bentuk digital. Seperti diketahui saat ini kebiasaan manusia telah banyak berubah, karena itulah sangat besar kemungkinan perpindahan peta dari sistem manual ke digital akan lebih disukai konsumen. Peta bentuk digital karena dianggap lebih praktis dan mudah, apalagi jika berbentuk infografis dinamis. Infografis sendiri merupakan kumpulan informasi dengan bantuan gambar, penggunaan dinamis dapat diartikan dengan penambahan unsur animasi dalam peta. Menggunakan teknik pengumpulan data berupa observasi langsung dan wawancara. Target penelitian ditujukan bagi para pengunjung Dufan yang meliputi segala usia, mulai dari kalangan pelajar, mahasiswa, dan keluarga dan melalui penelitian ini diharapkan akan diketahui informasi yang apa saja yang diperlukan pengunjung serta media dan desain yang dianggap efisien dan mudah dimengerti, sehingga melalui media peta bisa meningkatkan kepuasan konsumen.
\end{abstract}

Kata Kunci: infografis dinamis, kepuasan konsumen, media, sistem navigasi 


\section{Pendahuluan}

Ada banyak tempat yang bisa kita temukan di Jakarta sebagai tempat rekreasi. Jakarta sebagai ibukota Indonesia memiliki berbagai tujuan mulai dari taman kota hingga taman bermain, kebun binatang, mal, dan taman hiburan. Tujuan ini akan ramai pada akhir minggu, musim liburan sekolah dan hari raya. Salah satu taman hiburan terbesar di Indonesia adalah Dunia Fantasi atau dikenal dengan Dufan.

Berada di area luar ruang yang cukup luas, membuat pengunjung membutuhkan sebuah peta kawasan, untuk menjadi petunjuk bagi mereka dalam mencari arena permainan yang akan mereka kunjungi. Dufan sendiri menyediakan peta dalam bentuk cetak yang berbentuk brosur, yang diletakkan di area pintu masuk. Selain itu di kawasan bermain juga dilengkapi dengan standing map. Di Jakarta sistem peta manual masih dianggap cukup membingungkan dan susah untuk diingat, peta yang disajikan dalam bentuk gambar teknik yang bagi orang awam dianggap membingungkan. Seringkali hal ini membuat peta menjadi kehilangan fungsinya. Orang-orang lebih memilih untuk bertanya kepada orang lain untuk mengetahui arah yang mereka tuju daripada mencari sendiri informasi yang diperlukan. Seperti yang disebutkan dalam laporan hasil penelitian yang dikeluarkan oleh Computer Technology Research bahwa seseorang hanya akan mendapatkan $20 \%$ dari apa yang mereka lihat dan $30 \%$ dari yang mereka dengar. Sedangkan melalui multimedia akan mendapatkan 50\% dari apa yang mereka lihat dan dengar, sampai $80 \%$ dari apa yang mereka lihat, dengar dan berinteraksi dengan pada waktu yang sama. Oleh karena itu infografis digital yang dinamis diharapkan dapat menarik perhatian audiens untuk lebih mandiri untuk memanfaatkan informasi yang mereka perlukan.

Mengambil contoh taman bermain seperti Disney Land California misalnya, telah menggunakan sistem navigasi peta digital yang memudahkan pengunjung untuk mengakses informasi yang mereka butuhkan tentang wahana yang ingin mereka datangi. Sistem navigasi digital ini berkembang pesat saat ini. Sistem ini memanfaatkan teknologi multimedia yang sedang berkembang bahkan petunjuk arahpun dilengkapi dengan foto dan animasi. Untuk memudahkan penyajian informasi yang digunakan biasanya digunakan infografis. Terdapat 3 jenis infografis, yaitu infografis statis, bergerak dan dinamis. Infografis dinamis dilengkapi dengan animasi yang mewakili informasi yang ditampilkan (Jason, Josh dan Ross, 2014).

Perkembangan ilmu teknologi membuat orang-orang, baik dewasa maupun anak-anak tidak tertarik lagi dengan segala sesuatu yang berbau manual karena mereka telah mengenal dunia digital yang dianggap lebih menarik dan lebih praktis. Alasan lain orang-orang lebih suka dengan dunia digital karena dengan memanfaatkan teknologi multimedia informasi yang didapatkan menjadi lebih menarik karena dilengkapi dengan media-media lain, selain teks dan simbolsimbol standar yang kurang menarik perhatian. Media-media pendukung lain tersebut misalnya audio, video, foto dan animasi. Hal ini dianggap dapat menarik minat audiens. 
Seiring dengan kemajuan teknologi pula, konsumen menjadi lebih peka dan berani memberikan komentar serta penilaian terhadap pelayanan ditempat yang mereka kunjungi. Dilihat dari segi marketing, hal ini bisa menjadi hal yang menguntungkan sekaligus bumerang bagi penyedia jasa. Secara lebih rinci, penelitian yang dilakukan oleh Kariotis dan rekan (2007) menyebutkan bahwa ada 7 kondisi untuk suatu produk yang dinamis untuk dapat diterima oleh konsumen yakni: kerealistisan bentuk produk, ketersediaan informasi, ketersediaan detail organisasi, keterkaitan desain dengan kondisi asli, kemudahan penggunaan, keterkaitan lokasi dan tingginya akurasi dari produk. Untuk itu dianggap penting bagi penyedia jasa untuk selalu meningkatkan pelayanan pada konsumen sehingga bisa meminimalisir komentar negatif yang akhirnya bisa meningkatkan kepuasan konsumen.

\section{Metode Penelitian}

\section{Objek dan Lokasi}

Penelitian ini mengambil lokasi penelitian di Dunia Fantasi Taman Impian Jaya Ancol, khususnya area Dunia Fantasi. Dunia Fantasi yang merupakan lokasi yang memiliki wahana permainan cukup banyak dengan lokasi yang cukup luas. Kemudian, objek dari penelitian ini adalah sara peta informasi yang berada di Dufan.

\section{Teknik Pengumpulan Data}

Data dalam penelitian ini terdapat dua jenis data yaitu, data primer dan data sekunder. Data primer merupakan data yang diambil langsung dari lapangan berupa hasil wawancara, dokumentasi lapangan dan foto kondisi lapangan yang di ambil di lokasi Dunia Fantasi Ancol. Melalui proses observasi dan wawancara dengan pengelola, partisipan dalam penelitian ini yang adalah pengunjung Dunia Fantasi Ancol digolongkan menjadi 3 orientasi dengan jumlah masing-masing 5 kelompok (keluarga, kelompok muda/remaja, dan pasangan). Pengambilan data wawancara dengan pengunjung dalam penelitian ini dilakukan secara accidental (bertemu dan bersedia untuk diwawancara).

Sedangkan data sekunder adalah data yang didapat dari berbagai referensi atau pustaka yang mendukung. Pada tahap anilisis, akan disajikan pandangan subjek yang diteliti, menguraikan secara menyeluruh pengalaman dari subjek, kemudian mengkaitkannya dengan teori yang relevan.

Berikut merupakan gambar alur dari prosedur penelitian ini, yang terbagi ke dalam empat tahap. Tahap pertama merupakan tahap pra lapangan yang berisi pembuatan rancangan atau desain penelitian. Tahap kedua, tahap lapangan, pada tahap ini dilakukan observasi, pengumpulan data melalui wawancara, dan dokumentasi. Berikut adalah tahap ketiga, tahap analisa, dimana data yang telah diperoleh di analisis. Tahap terakhir adalah tahap penyusunan laporan hasil penelitian. 


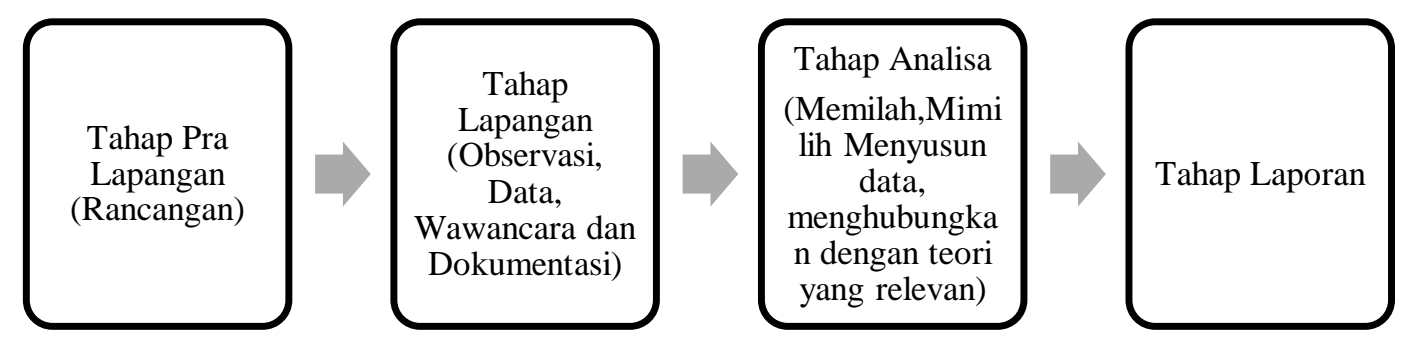

Gambar 1: Prosedur Penelitian

\section{Hasil Penemuan dan Diskusi}

Dari hasil observasi, peta yang ada di Dufan ada dua macam, yaitu standing map dan hand map. Standing map ada 3 buah jumlahnya. Standing map ini semuanya berada di dalam kawasan Dunia Fantasi yang tersebar di berbagai kawasan di dalam Dunia Fantasi. Secara fisik, standing map terlihat sudah usang. Menurut Bapak Andi standing map sudah ada sejak lama, sekitar 24 tahun yang lalu dan belum diganti sampai sekarang. Standing map yang ada di area Dufan ini juga terlihat dibuat permanen sehingga tujuan digunakan untuk jangka waktu yang panjang.

Untuk petanya sendiri, belum ada pembaharuan sejak diadakannya peta tersebut sehingga wahana-wahana yang baru belum masuk ke standing map. Oleh karena itu, bisa dikatakan informasi pada standing map tidak lengkap dan kurang terkini. Selain itu, dari segi ergonominya, standing map yang ada di Dunia Fantasi terlalu tinggi sehingga sulit dijangkau oleh anak-anak. Informasi dalam peta juga terlalu kecil ukurannya, terutama ukuran hurufnya.

Selain standing map, ada jenis peta lain yang disediakan oleh pihak Dunia Fantasi, yaitu hand map. Peta ini lebih praktis karena bisa dibawa-bawa oleh pengunjung. Kelebihan lainnya dibandingkan dengan standing map adalah informasi yang ada di dalamnya lebih lengkap. Informasi yang ditampilkan sama dengan standing map, yaitu menampilkan letak-letak wahana yang ada di Dunia Fantasi. Perbedaannya dengan standing map adalah hand map diperbaharui secara berkala sesuai dengan penambahan wahana baru yang ada di Dunia Fantasi. Akan tetapi, kekurangan dari hand map ini adalah peta jenis ini beresiko terkena air atau rusak pada saat menaiki wahana. Selain bisa rusak terkena air, biasanya hand map sering tertinggal, terjatuh, hilang dan bahkan sobek pada saat dibawa-bawa oleh pengunjung.

Data yang didapatkan dari hasil wawancara dibagi menjadi beberapa kelompok (1) Sistem navigasi. Dalam sistem navigasi ditemukan bahwa (a) Peta informasi Dufan ternyata sudah kehilangan fungsinya sebagai peta atau yang dikenal sebagai penunjuk arah. (b) Peta lipat berbentuk brosur sering ketinggalan, 
Anny Valentina, Richard Andrew : Infografis Dinamis Sebagai Pengganti Peta Konvensional pada Kawasan Bermain (Studi Kasus : Dunia Fantasi)

rusak terkena air, sehingga dibutuhkan peta multimedia, sekaligus untuk menaikkan brand image Dufan. (2) Media informasi yang komunikatif bisa dicapai melalui bantuan desain. (a) melalui pemilihan jenis huruf (b) melalui tata letak (c) ilustrasi dan penggunaan simbol. (3) Meningkatkan kepuasan konsumen melalui penambahan pelayanan berupa peta interaktif

\section{Diskusi}

Dari hasil temuan diatas kemudian dikaitkan dengan beberapa hasil penelitian dan teori yang relevan. Berdasarkan penelitian yang dilakukan oleh Kariotis dan rekan (2007) menyebutkan bahwa ada 7 kondisi untuk suatu produk yang dinamis untuk dapat diterima oleh konsumen yakni:

\begin{tabular}{|c|c|c|c|}
\hline $\begin{array}{c}\text { 1. Kerealistisan } \\
\text { bentuk produk }\end{array}$ & $\begin{array}{c}\text { 2. Ketersediaan } \\
\text { informasi }\end{array}$ & $\begin{array}{c}\text { 3. Ketersediaan } \\
\text { Detail Organisasi }\end{array}$ & $\begin{array}{c}\text { 4. Keterkaitan } \\
\text { desain dengan } \\
\text { kondisi asli }\end{array}$ \\
\hline \begin{tabular}{c|c|c|} 
5. Kemudahan \\
penggunaan
\end{tabular} & $\begin{array}{c}\text { 6. Keterkaitan } \\
\text { lokasi }\end{array}$ \\
\hline
\end{tabular}

Gambar 2: Tujuh Kondisi Produk Dinamis Dapat Diterima Konsumen

Dari ketujuh hal tersebut diatas, sangat memungkinkan untuk bisa diwujudkan. Infografis dinamis sangat realistis untuk bisa diwujudkan di era digital saat ini. Dufan memiliki banyak informasi yang dapat diberikan dan ketika dikemas dalam bentuk infografis, informasi akan lebih mudah dan cepat sampai pada pengguna tentu saja dengan dibantu layout yang baik.

Berikut isi dari Peta cetak Dufan:

* Judul Peta : "Peta Dunia Fantasi"

* Informasi-informasi wahana yang dibagi dengan menjadi 7 kawasan :

- Kawasan Amerika : Lorong Sesat, Poci-Poci, Niagara

- Kawasan Indonesia : Alap-Alap

- Kawasan Jakarta : Turangga-rangga, Istana Boneka

- Kawasan Eropa : Kicir-kicir

- Kawasan Asia : Bianglala, Kora-kora, Gajah Bledug

- Fantasi Hikayat : Pontang-Panting, Ontang-Onting, Rajawali, Halilintar, Ombaga-Ambigu

Sarana umum seperti WC, Telefon Umum, Mushola, Toko Souvenir, Restoran, Bagian Informasi, dan Puskesmas.

* Pintu Gerbang dan Pintu Keluar

* Logo Dufan 


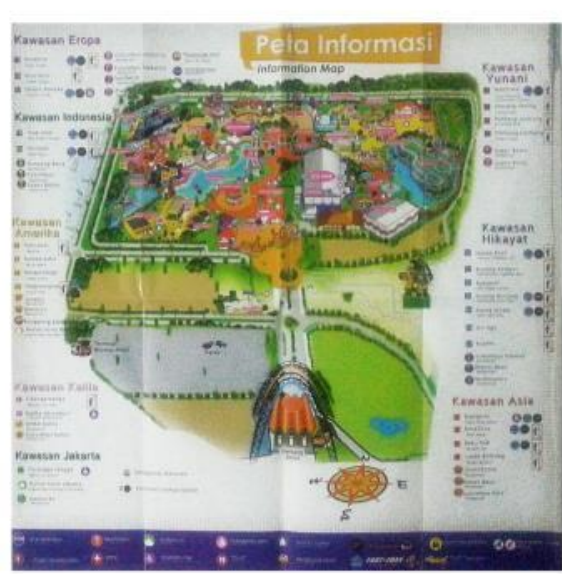

\section{Tampak Depan}

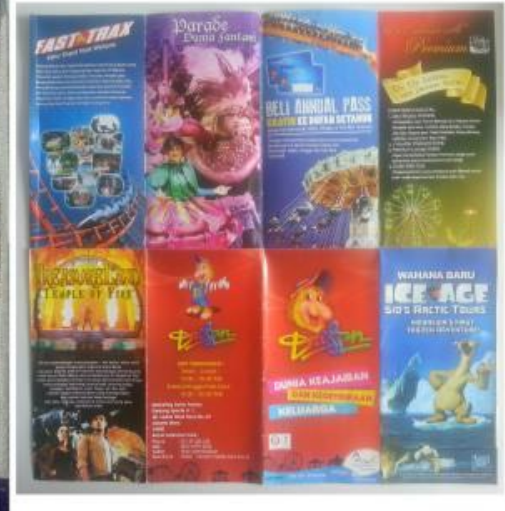

Tampak Belakang

Gambar 3: Desain Peta Cetak Dufan yang Komplek, Banyak Informasi

Melalui kemajuan teknologi, penyampaian lokasi yang lebih akurat bahkan dilengkapi dengan foto lokasi secara 360 derajat-pun memungkinkan untuk disajikan melalui google map. Pemanfaatan teknologi bisa dilihat dari taman bermain sejenis Dufan (Disneyland) yang telah memberikan layanan berupa peta digital.

Infografis sendiri dibuat untuk memberikan kemudahan dengan bantuan visual dalam membaca informasi yang cukup kompleks. Bentuk akhir dari infografis biasanya didominasi visual daripada informasi teks. Dalam bentuk dinamis infografis memungkinkan pengguna untuk bisa berinteraksi. Selain itu untuk memudahkan pengguna hal lain yang bisa dilakukan adalah dengan mempertimbangkan prinsip-prinsip desain, huruf dan penggunaan gambar atau simbol yang mudah dimengerti juga sangat penting. Penggunaan warna bisa menjadi pertimbangan untuk membantu memudahkan dalam pengelompokan area.

Dalam penggunaan huruf misalnya, penggunaan huruf harus mempertimbangkan tingkat keterbacaan, apalagi jika menyangkut huruf untuk informasi dan harus diletakkan sebagai bagian dari keterangan gambar. 


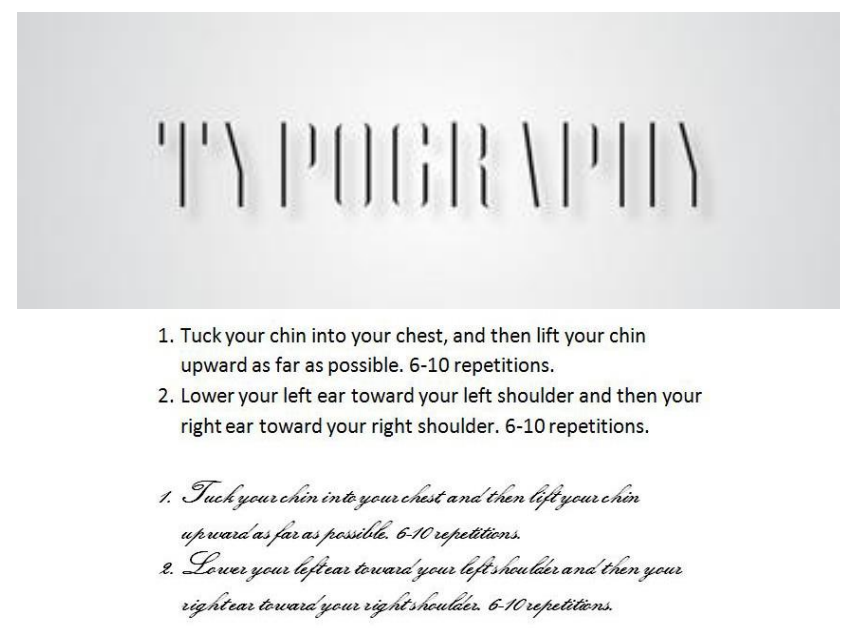

Gambar 4: Contoh Huruf yang Memiliki Tingkat Keterbacaan Rendah (Kiri) dan Perbandingan Jenis Huruf

Pada penggunaan warna, warna-warna yang cerah dan terang akan memberi efek positif bagi yang melihat karena memberi semangat, memberi rasa estetika, memperkuat daya imajinasi dan memperkuat rangsangan motorik. Oleh karena itu, prinsip ini harus diterapkan dalam pembuatan peta Dunia Fantasi yang mana merupakan tempat rekreasi dan tempat hiburan sehingga warna-warna yang cerah bisa lebih dominan. Selain itu melalui warna bisa juga memberikan kaitan dari masing-masing warna dengan lokasi kawasan. Dunia Fantasi sendiri terbagi atas 8 kawasan tematik, yaitu Kawasan Eropa, Kawasan Indonesia, Kawasan Yunani, Kawasan Amerika, Kawasan Hikayat, Kawasan Kalila, Kawasan Jakarta, dan Kawasan Asia. Berikut adalah rekomendasi warna untuk kawasan di Dunia Fantasi.
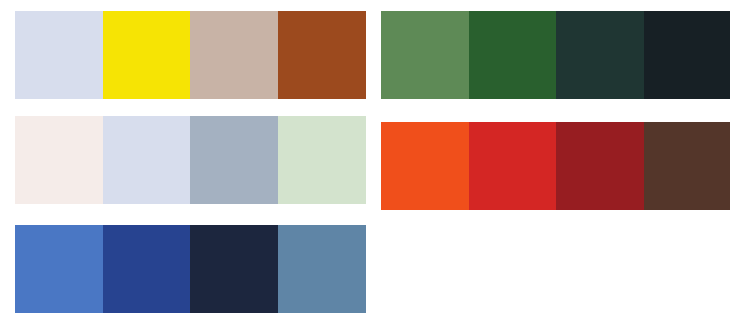

Gambar 5: Referensi Kawasan Eropa
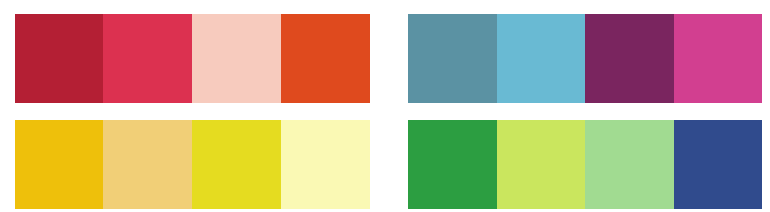

Gambar 6: Referensi Kawasan Indonesia
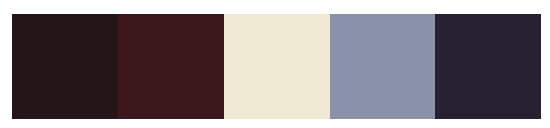

Gambar 7: Referensi Kawasan Yunani 


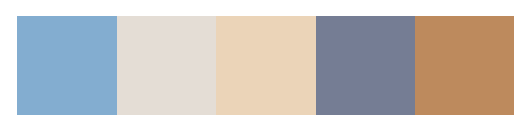

Gambar 8: Referensi Kawasan Amerika

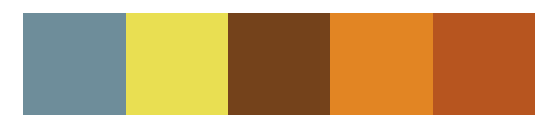

Gambar 9: Referensi Kawasan Hikayat

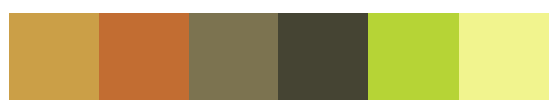

Gambar 10: Referensi Kawasan Kalila

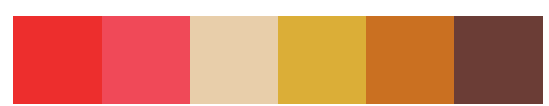

Gambar 11: Referensi Kawasan Jakarta

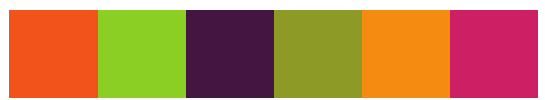

Gambar 12: Referensi Kawasan Asia

Akurasi dari peta dalam bentuk media infografis dinamis seperti ini sangat mungkin untuk dibuat. Mengambil contoh pada Disneyland yang mampu menghadirkan layanan seperti lamanya antrian pada tiap wahana. Lima hal yang perlu diperhatikan untuk mengukur tingkat kepuasan konsumen, yaitu : (1) Ekspektasi pelanggan; (2) Kualitas yang dipersepsikan; (3) Nilai yang dipersepsikan; (4) Keluhan pelanggan; (5) Loyalitas pelanggan.

Melalui sebuah infografis dinamis apa yang diharapkan pelanggan seperti kemudahan dalam mencari wahana akan bisa teratasi, selain ini pengunjung juga akan sangat terbantu dengan adanya informasi lokasi-lokasi penting, serta jika dilengkapi dengan informasi seperti panjangnya antrian, hal ini akan membantu meminimalisir keluhan pelanggan sehingga diharapkan dengan rendahnya tingkat keluhan konsumen, maka konsumen akan semakin loyal pada Dufan, sehingga Dufan akan menjadi pilihan pertama jika konsumen akan berwisata.

\section{Simpulan}

Sistem navigasi lokasi wahana yang ada di Dunia Fantasi sudah saatnya dilakukan peremajaan. Peta Dunia Fantasi masih menggunakan sistem peta konvensional juga perlu dilakukan redesign, dengan lebih mempertimbangkan prinsip-prinsip layout dan desain, sehingga lebih memudahkan bagi pengguna, dalam hal ini konsumen. Sistem navigasi digital mulai diminati oleh pengunjung Dunia Fantasi. Berbagai kemudahan akan didapatkan pengunjung, mulai dapat dengan mudah mengakses informasi tentang wahana yang ingin mereka kunjungi hingga memudahkan mereka mencari wahana yang dituju. Melalui sistem navigasi digital berupa infografis Dinamis, akan sangat membantu peningkatan kepuasan pada konsumen. 
Anny Valentina, Richard Andrew : Infografis Dinamis Sebagai Pengganti Peta Konvensional pada Kawasan Bermain (Studi Kasus : Dunia Fantasi)

\section{Saran}

Untuk pengembangan lebih lanjut disarankan menyediakan sistem navigasi berbentuk infografis dinamis yang lebih efektif dan efisien bagi pengunjung Dufan, antara lain :

- Informasi pada peta seharusnya mengenai letak wilayah lebih jelas, dibantu melalui pengelompokan warna dan sisitem layout yang benar;

- Sistem navigasi berupa navigasi digital mulai diminati oleh pengunjung berdasarkan hasil wawancara;

- Sistem navigasi harus mempertimbangkan prinsip-prinsip desain, sehingga akan mudah dimengerti dan mudah digunakan; sehingga apa yang ingin dikomunikasikan, tersampaikan dengan jelas;

- Sistem navigasi digital sendiri bisa diunduh didalam gadget pengunjung sehingga lebih efisien untuk dibawa kemana-mana.

\section{Ucapan Terima Kasih:}

Terima kasih kepada Direktur Penelitian dan Pengabdian kepada Masyarakat Universitas Tarumanagara yang telah memberikan kesempatan untuk melakukan penelitian ini, juga kepada seluruh ketua dan staff di DPPM Untar yang telah membatu dan mendukung. Pengelola Dunia Fantasi yang telah memberikan kesempatan untuk melakukan wawancara dan memberikan informasi untuk kebutuhan penelitian. Rekan-rekan yang telah membantu proses penelitian.

\section{Daftar Pustaka}

Angela, S (2013). Perancangan Layout. Diakses Oktober 06, 2016. Terarsip di : http://dspace.library.uph.edu:8080/bitstream/123456789/2253/10/0232008 0115_Chapter2.pdf

Artsparx. (2011). Greek Revival. Diakses November 11, 2016. Terarsip di : http://www.artsparx.com/hist_colorgreek.asp

Bayer, Herbert., Gerstner, Karl., \& Hara, Kenya. (2009). Graphic Design Theory Readings From The Field. New York : Princeton Architectural Press.

Brandi Hussey (2011). Color Pallette : Chinese lantern. Diakses November 12, 2016. Terarsip di : http://www.brandigirlblog.com/2012/10/color-palette127-chineselantern. html

Color Bomb (2013). Brown Color Image Example. Diakses November 12, 2016. Terarsip di : http://www.colorcombos.com/tags/colors/brown

Color Bomb (2013). Hex Web Color. Diakses November 12, 2016. Terarsip di : http://www.colorcombos.com/colors/BA6222

Gilbert, Jennifer (2013). Warm Colors?, Diakses November 11, 2014. Terarsip di : http://www.pinterest.com/jenlovesmichael/warm-colors/

Healey, Matthew. (2008). What Is Branding?, New York : Rockport.

Irawan, Koko. (2010). Potensi Objek Wisata Air Terjun Serdang Sebagai Daya Tarik Wisata Di Kabupaten Labuhan Batu Utara. Kertas Karya. Program Pendidikan Non Gelar Pariwisata : Universitas Sumatera Utara.

Lankow, Jason., Ritchie, Josh., \& Crooks, Ross. (2012). Infografics - The Power 
of Visual Story Telling, New York : John Willey and Sons Inc.

Muzack, Zacky. (2013). Psikologi Pariwisata dan Kepribadian Wisatawan. Diakses Oktober 03, 2016. Terarsip di : http://zackyeducations.blogspot.com/2013/01/psikilogi-pariwisata.html

Polyvore (2013). Design Seeds for All Who Love Beach. Diakses November 20, $2016 . \quad$ Terarsip di

http://www.polyvore.com/design_seeds_for_all_who/thing?context_id=260

9248\&context_type $=$ lookbook\&id $=66311667$

Product Finishing (2013). White Stay Atop of Cars Color Rank. Diakses November 11, 2016. Terarsip di : http://www.pfonline.com/blog/post/whitestays-atop-the-worlds-car-colorranks

Rustan, Surianto. (2010). Font \& Tipografi. Jakarta : PT Gramedia Pustaka Utama.

Rustan, Surianto. (2010). Layout, Dasar dan Penerapannya, Cetakan Kedua. Jakarta : PT Gramedia Pustaka Utama.

Sarwono, Jonathan., \& Lubis, Hary. (2007). Metode Riset untuk Desain Komunikasi Visual. Yogyakarta : Andi.

SCI i-color creation (2014). Inilah Trend Warna di Tahun 2014. Diakses November 11, 2016.Terarsip di : blogspot.com/2013/04/inilah-warna-trend-di-tahun-2014.html

Siregar, AS. (2012). Brand Destination. Diakses Oktober 06, 2016. Terarsip di : http://repository.usu.ac.id/bitstream/123456789/33920/4/Chapter\%20II.pdf

Social Psychology for Social Good. (2010). Tools for Changing The World. Diakses November 20, 2016. Terarsip di : http://toolsforchangingtheworld.com/let-us-make-ourselves-perfectlyclear/

Suherman. (2014). Perkembangan Anak. Jakarta : PT Gramedia Pustaka Utama.

Studio, Desain. (2010). Teori Gestalt dalam Desain Grafis. Diakses Oktober 06, 2016. Terarsip di : http://www.desainstudio.com/2010/12/teori-gestaltdalam-desaingrafis. html\#sthash.6ZLBprMB.dpuf

Supriyono, Rakhmat. (2010). Desain Komunikasi Visual - Teori dan Aplikasi, Yogyakarta : Andi.

Taylor, David. (2014), Understanding Composition. United Kingdom : AE Publications.

Teori Warna. (2011). Diakses Oktober 06, 2016. Terarsip di : http://thesis.binus.ac.id/doc/Bab4/2011-2-00276-DS\%2520bab\%25204.pdf

Tenbears. (2011). Hard to Read Typography. Diakses November 20, 2016.Terarsip di : http://www.coolastenbears.com /hard-to-readtypography-7

Thomas, Chris. (2013). You Are Here. Amsterdam : BIS Publishers.

Woolman, Matt. (2008). Digital Information Graphics. New York : Watson Guptill. 